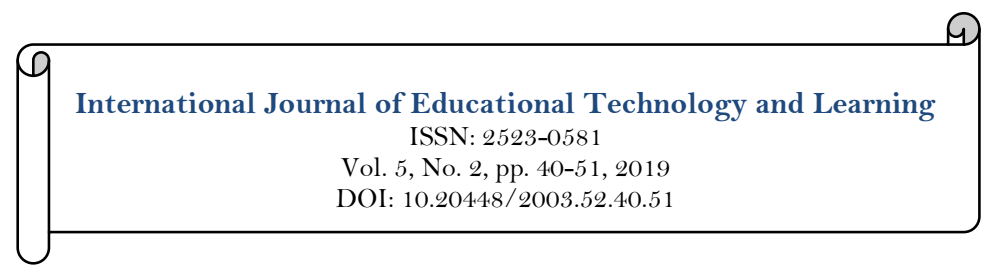

\title{
check for
updates \\ Evaluation Results of a Teacher Professional Development Program in Greece on Gifted and Talented Children Education (GATCE)
}

\author{
Efthymia Gourgiotou ${ }^{1}$ \\ Ioanna Katsavria ${ }^{2 *}$ \\ Eleftheria Basagianni ${ }^{3}$
}

'Assistant Professor University of Crete, Greece.

${ }^{-}$Gifted Education Specialist Program Director, Greece.

Email: ioanna.katsavria@icloud.com

${ }^{s}$ Educational Consulter, Greece.

\section{Abstract}

According to research results, gifted students need early intervention processes. However, school administrators and teachers have limited knowledge of the identification of giftedness and the development of programs for the specific student population, especially in Greece. An eightmonth training program was designed and implemented to meet the $K-6^{\text {th }}$ grade teachers' learning needs about gifted education in a school district in Central Greece. The objective of this study is (was) to evaluate the results of the in-service teachers' professional development program on gifted and talented children's Education (GATCE) in Greece and its impact to the participants. The sample comprised of $47 \mathrm{~K}$-6th grade teachers, 2 trainers and 1 education consultant. The results showed that most of the participators were satisfied with the eight-month training and considered it would help them effectively integrating theory about gifted students' education into their instruction. Study results also indicated that the majority of the participants were involved in relevant tasks regarding the development of their lesson plans and the implementation of activities in the classroom. Since the completion of the training, the participants worked in groups to enrich the national curriculum and to develop activities for their gifted students.
Keywords:

Gifted and talented

Primary teacher training and professional development

Program evaluation

Greek case.

Licensed:

This work is licensed under a

Creative Commons Attribution 4.0

License.

Publisher:

Scientific Publishing Institute

Funding: The research was funded by Mrs. Ioanna Katsavria.

Competing Interests: The authors declare that they have no competing interests.

Acknowledgement: We gratefully acknowledge the support and generosity of Dr. Brenda Romanoff, Professor in the

Education Department at UNCC in U.S.A, Dr. Anna Athanasopoulou, Math Lecturer in the Department of Mathematics and Statistics at UNCC in U.S.A., Mrs. Clare Wynter, Copyright Officer and Assistant Director in the Department of Education in Australia, Mr. Petro Damiano, President of European Prison Education Association-

Hellas, and the parents of gifted students in Greece, without them the present program could not have been completed.

\section{Introduction}

It is accepted widely that gifted and talented children are the ones that show higher mental, socialemotional, expressive and creative skills compared to the rest of the children, who require a supportive environment responding to their needs and improvement (Johnsen, 2003).

According to the definition given by the USA Department of Education in 1972, gifted and talented students are thought to be the ones who, after having been evaluated by specialists, have been certified as possessing exceptional abilities and are capable of high scores. Those students display or have the ability to display high performance in a) general mental ability, b) special academic performance, c) creative or productive way of thinking, d) leadership ability, e) visual or expressive arts and f) the psychological sector. 
Ever since, many psychologists, teachers, and researchers have attempted to define gifted and talented students even though no separated study can effectively incorporate the various parameters of the relevant studies. This issue was associated with the modern consideration of intelligence and it led to the development of various scientific approaches from different scientific fields. The modern consideration of what intelligence is stems from adopting multidimensional theoretical models, such as the ones by Gardner, Heller, Milgram, Renzulli, et al. and has affected mainly the educational procedure. These theories are based on interaction and composition of different factors and not on a single-dimensional interpretation of a phenomenon (Pfeiffer, 2012, 2015; Tourón, Peralta, \& Repáraz, 1998; Tourón, Repáraz, \& Peralta, 2006). A redefining of the terms "gifted" and "talented" has been suggested, so that the cognitive and academic content of these terms can be enriched with elements related to creativity, motives, and interests.

According to Gardner (1983) seven types of intelligence can be discerned (language, logical-mathematic, space-related, musical, physical-kinetic, personal and interpersonal), thus affirming the modern multifactor view of being gifted and the multiple dimensions through which the dynamics of being gifted are defined. Respectively, the Munich model (Heller, 1992) considers "gift" as a product of genetic and environmental factors and adopts a categorization of intelligence, similar to Gardner's, in five dimensions: mental ability, creativity, social ability, artistic ability, and psychokinetic ability. In Milgram (1991a) Milgram (1991b), being gifted is depicted to four categories of factors, two of which deal with sides of intelligence, the general mental ability, and the special mental ability, and two dealing with aspects of creativity, general creativity or creative thinking and the special creative talent. Finally, Renzulli (1978) summarizing the studies by many experts, concluded that gifted behavior is expressed by people with high intelligence and perception -above averagebut not necessarily combined with creative thinking and the ability to dedicating oneself to a task (persistence, acceptance of creative criticism, reviewing strategies, etc). Individuals who are capable of developing this complex group of characteristics and applying them to any aspect of their lives need several educational opportunities and services, which are usually not provided by the traditional educational curricula (Renzulli, 2012).

\subsection{Educating Gifted and Talented Students}

The views mentioned above as well as many others developed with the notion of giftedness somehow affected the methods of educating these children. The solution to the whole issue was nevertheless not considered satisfactory. Today, in most western countries, gifted and talented students coexist in a conventional classroom along with students of all levels and capacities based on the criterion of biological age or attend special classes. Research results encourage institutions and schools educating gifted and talented students to adopt educational methods which would liberate the children with special abilities from the compulsive enforcement of a single curriculum; such a curriculum does not satisfy their needs and thus takes their creativity and their contribution to sciences, arts and civilization away. Therefore, in many of these countries differentiated programs are set up to help these students in their personal and social growth as well as school achievement.

The development of specific curricula for gifted and talented children is based on the following principles:

a. inclusive education, developed in the framework of Salamanca declaration (UNESCO, 1994) proposing a school for all children and adapting the common curriculum to the needs of all children, whatever their learning level might be, b. The psychological theory of motives, also known as "+1 theory", according to which the ideal learning and development frame is the collective one, which moves in the higher learning levels of students and above (Tomlinson, 2001; Vygotsky, 1997) and c. The theory of differentiated learning, according to which teaching methodologies/didactics recognize the necessity of the harmonic coexistence of "ordinary" and "exceptional" thus including various forms of differentiated teaching.

Mixed-ability classes, in the context of inclusive education, face many challenges and problems. The primary challenge regards the in-service training of personnel responsible for these students, such as teachers, school psychologists, managerial staff, education supervisors, curricula designers, art teachers, music teachers and other specialists, who should be adequately trained to appreciate these children's potential, improve them and provide additional opportunities for all students to achieve the highest point of their capabilities.

From all the participants mentioned above, the active teacher's role seems to be of vital importance since he/she is the one who detects class children possessing such skills and evaluates their unique traits.

\subsection{Training as a Model of Professional Development}

Consequently, it is of great importance to educate in-service teaching staff, so that they can support the gifted and talented students' education. Unfortunately, despite the considerable attention provided to the education of gifted pupils, the training of teachers has been neglected resulting in the inability to support these children in the future (Reid \& Horváthová, 2016).

Training can help by providing teachers -especially in cases of novice teachers teaching experience or prior training- necessary knowledge, qualifications and self-confidence to recognize, appreciate and apply the qualities of the gifted and talented students in their classroom and school community (Fraser-Seeto, 2013). Furthermore, in the context of such training teachers have the chance to make better use of the knowledge in 
the field, professional moral principles, methods and techniques of teacher planning for the enrichment of teaching practice, as well as the involvement in constant learning and professional development (NAGC \& CDGP, 2013).

The relevant literature review has shown that for teachers to be effective, teacher training programs on gifted and talented students should include among other things a. General information on the education of students with special mental capacities and talents, b. The leading scientific approaches on the subject of talent and gifts, c. Familiarization with i. The sense of creativity, ii. The ideas of the emotional aspect of giftedness and talent, iii. The general and special characteristics of talented students, iv. The idea of 'twofold' special ability, d. Suggestions on specialized teaching plans for gifted and talented students, and e. The implementation of projects with the help of a specialized mentor for the practical application of knowledge and skills acquired during the training program (Sparks \& Loucks-Horsley, 1989).

The training of in-service staff aiming at a context of knowledge and skills as the ones mentioned above is essential to the professional development of teachers. Teachers themselves expand their knowledge, reexamine, and revise their initial perceptions of difference and giftedness through critical thinking to modify their practice accordingly.

According to the principles of these curricula, teachers of gifted and talented students are generally responsible for one or more roles: a. Planning enriched school activities for students and teachers, b. Collecting and disseminating necessary information related to innovative teaching practices, teaching material, sponsors and the offer of special opportunities for gifted children, c. Managing daily activities in ways that correspond to these children's pace and abilities, d. Unifying the daily curriculum with the SEN program, e. Advising and guiding students, parents and teachers on specific problems related to the subject of giftedness, and f. Encouraging these children's creative, productive and leading skills (NAGC \& CDGP, 2013).

Teachers of regular classes are often the first to identify the dynamics of gifted and talented students or the early signs indicating a student's abilities provided that they are aware of the characteristics of giftedness and these students' needs. Through the diagnostic process teachers of ordinary classes can help gifted and talented children to access special services and work with the expert teachers responsible for these children's education. Both teachers of ordinary classes and those of special ones should see themselves as members of a team and not as antagonists. Each of them should respect the other's contribution to the education of gifted and talented students. Together they should be able to develop the daily program, teaching strategies, choice of material, curriculum targets, implementation of activities and evaluation processes.

Results of various studies have shown that training future teachers for the education of gifted and talented students has increased their understanding of the sense of giftedness, and has helped them evaluate their personal interests and abilities that would lead them to self-reflective awareness (Kabadayi, 2016) but research on or evaluation of the effects of these training models is meager (Choe, 2011, 2016; Say1, 2018; Tortop, 2014). Studies (Hansen \& Feldhusen, 1994; Mönks \& Pfluger, 2005) indicated that teachers that were trained in gifted education were more competent and created a friendly classroom environment in comparison with the ones that didn't have any training in this field. In Hansen and Feldhusen (1994) study, that was conducted with 82 teachers in gifted education, found out that participants emphasized more on higher level thinking skills and discussion, and less on lecture and students' academic performance (grades) that usually are important for teachers that didn’t receive any training (Hansen \& Feldhusen, 1994).

\section{The Context of Gifted and Talented Education in Greece}

Although we can find the basic ideas of talent support in Classical Greek philosophy and although the word "talent" has its roots in Ancient Greece for use in our European and global cultural heritage, talent support is not given its proper place and recognition in the present Greek educational system.

Despite, also, a long history of educational provisions for gifted and talented education internationally, in Greece there remains a lack of response to research and government inquiries that maintain the need for increased teacher training, especially at in-service level.

Gifted education programs have developed and implemented in different countries worldwide since the last century. However, in some countries like Greece, there is a lack of response to research and government inquiries that maintain the necessity of increased teacher training, especially at the in-service level. Gifted students are, in our country, a significant source of the high intellectual capacity to solve future problems and the ability to take leadership roles in society. Despite this, the first educational policy that explicitly addressed Gifted students learning needs in Greece was established in 2003 (Law, 3194/2003, 3699/2008), where for the first time, a legal document mentioned that "special educational treatment might benefit people who have special abilities and talents".

In addition, the Department of Special Education of Pedagogical Institute of Athens and the Ministry of Education published a concise Guide to their Education for students that exceled in intellectual level and for the ones that were talented Students with Intellectual Capabilities and Talents, Gross et al. (2004). Few years later, the Ministry of Education published a new law, reconsidering the definition of students with special educational needs. 
(Law, 3699/2008). According to this document," Students with special needs who have one or more special mental abilities and talents developed in a higher level than the expected for their age require special education."

The Ministry of National Education and Religion, after the Pedagogical Institute of Athens invitation, suggests the development of evaluation principles and educational programs to be implemented for these students to some university faculties or departments which are possibly interested.

So, gifted students in Greece, most of the times in academic level in Greece usually have been catered at specific level with selective schools and enriched curriculum that were designed to meet their learning needs. Unfortunately, a limited number of gifted students that live in urban places study in these schools. The ones that live in rural areas or away from urban locations face difficulties to gain access in these schools and to develop their potential in full.

However, gifted students learning needs most of the times remain unmet, in specialized and mainstream schools, due to the lack of teachers' professional development programs in gifted education. Teacher's preparation University programs prepare teachers to teach diverse student population and the ones with special needs within mainstream classrooms. In the contrary, there no provisions for in-service teachers' training specifically in gifted students learning and socio-emotional needs. In the lacking of implementing either the above laws or the Guide, today's educational reality has created a large void in support programs in gifted education and to train teachers on the specific In the lacking of implementing

Either the above laws or the Guide, today's educational reality has created a large void to support programs in gifted education and to train teachers on the specific student population needs. The existence of this void puzzled sensitized the School Counsellors in Voiotia (Veotia) who, taking into account the: a) Scientific research data related to this issue, b) Initiatives of international and Greek organizations for the Gifted students, c) Specific Legislation in Greece (as already mentioned), and d) Opportunity is given to them through the institutional framework: Law 1566/85, art. 55, \& 1., Presidential Decree 200, art.

12, paragraph 1 Presidential Decree 201 UNHCR

F353.1/324/105657/D1/t.V/FEK1340/16-10-2002, art. 9, clause 2, par. d \& g decided to materially support the following Program GATCE having as the main goal the teacher's awareness and sensitiveness in support of the learning and socio-emotional needs of gifted students. Responsible for the program's organization was the 29th School District's Educational Counsellor, the School Counselors of the 1st, 2nd, 3rd, and 4th District of Primary Education namely Dr. Spiridoula Katsifi, Mrs. Asimina Skondra, Dr. Anna Zouganeli, and Mr. Apostole Georganta. The program was implemented based on the principles of adult learning, with scientific support. Responsible for the program's development and implementation was Mrs. Ioanna Katsavria, who is specialized in gifted education and has conducted postgraduate research on the career preferences and skills of gifted students.

\section{Teacher Professional Development Program on Gifted and Talent Children's Education} (GATCE)

\subsection{Aims of the Program}

In-service teacher's training was focused on the development of competency and understanding of gifted students' needs.

Specifically, in-service teachers training program were expected to:

a) Develop awareness of teaching gifted students, which includes an understanding of the teacher's role in the following: school improvement processes, school accountability, and long-term professional development planning,

b) Develop awareness among elements of cultural and social life through the educative process, which includes generating the ability to communicate effectively with gifted students' parents (children, other site-based professionals, and persons representing the community - agencies),

c) Understand, nominate, identify, assess, and develop individual lesson plans to accommodate the emotional, social, physical, and learning needs of gifted students,

d) Plan, deliver, and assess instruction that integrates projected and non-projected educational materials that are appropriate for gifted students,

e) Acquire and apply skills to successfully manage a classroom and the interpersonal relationships, which enhance the educational environment and promote gifted students' learning, and

f) Demonstrate a rich understanding of the philosophical foundations of gifted students' learning and its contribution to achieving the school curricular goals.

\subsection{The Training Process}

The training process is according to the literature which is related to teacher's professional development, the current training program in gifted education for the in-service teachers has espoused a synthesis approach (Grow-Maienza, 1996) between theory and practice and the opposite. The training comprised only venuebased activities developed to prepare teachers with the theoretical knowledge of subject matter and teaching methods (Van Tassel-Baska \& Johnsen, 2007). 
Furthermore, the training content drew substantially from the Professional Development Package for Teachers in Gifted Education from the Gifted Education Research Resource and Information Center (GERRIC) of the University of New South Wales (UNSW) comprised the following three areas of Professional Development topics:

1. Professional program development (conducting a needs assessment, writing a philosophy, designing an identification process, selecting delivery options, creating action plans).

2. Identification: characteristics of gifted children, identification of giftedness, gifted students social and emotional needs).

3. Instructional strategies: Compacting pre-assessment strategies, higher-order thinking skills, brainstorming, problem-solving, extended activities, modification of assignments, differentiation.

Up to 47 K-6th grade, in-service teachers participated in the training due to the online applications' submission. Good knowledge of English and computers use was considered essential for teachers' participation in the training. Teachers' presence was mandatory at all meetings. The total contact time was 42 hours (3hours/meeting, 14 meetings in total) see Table 1.

Table-1. The in-service pilot professional development program GATCE for the teachers about gifted education.

\begin{tabular}{l|l}
\hline \multicolumn{2}{c}{ Pilot Professional Development Program Contact hours } \\
\hline 14 Irregular sessions & 42 hours (3 hours per session over 8 months) \\
Study group preparations & 21 hours (1 1/2 per session) \\
Self-study & 42 hours (3 hours preparation per session) \\
Summary & 105 hours \\
\hline
\end{tabular}

The teachers' in-service pilot training program in gifted education contact hours included: 14 irregular sessions, 44 hours ( 3 hours per session over 8 months). Study group preparations included: 21 hours ( $1 \frac{1}{2}$ per session). Self -Study included: 42 hours (3-hour preparation per session). Total summary, 105 hours in total. Upon in-service teachers training completion, a Certification was given, by the School Counselors, stating the training's program title and total hours.

The in-service training program has been conceptualized as a long-term program. The University of Crete was to support the program continuously by monitoring and evaluating it through formative and summative assessments.

The venue of the training program has been chosen to be the 4th Primary School of Thiva, Voiotia district. The meeting dates (and contents of the teaching) modules are described in detail in the following table see Table 2:

Table-2. The in-service professional development program GATCE schedule for the 47 in-service public-school teachers.

\begin{tabular}{|c|c|c|}
\hline \multicolumn{3}{|r|}{ 1st Meeting } \\
\hline Date/Time & Title & Description \\
\hline $\begin{array}{l}12 / 10 \\
5-8 \text { p.m. }\end{array}$ & $\begin{array}{l}\text { Introduction of the } \\
\text { program. }\end{array}$ & $\begin{array}{l}\text { Introduction to the training program's goals \& objectives and expected } \\
\text { outcomes. Nomination of trainees learning needs and goals about the } \\
\text { program. }\end{array}$ \\
\hline \multicolumn{3}{|r|}{$2^{\text {nd }}$ Meeting } \\
\hline Date/Time & Title & Description \\
\hline $\begin{array}{l}19 / 10 \\
5-8 \text { p.m. }\end{array}$ & $\begin{array}{l}\text { The education of gifted } \\
\text { and talented students } \\
\text { worldwide. }\end{array}$ & $\begin{array}{l}\text { Introduction of the gifted education policies and programs around } \\
\text { the globe }\end{array}$ \\
\hline \multicolumn{3}{|r|}{$3^{\text {rd }} \& 4^{\text {th }}$ Meeting } \\
\hline Date/Time & Title & Description \\
\hline $\begin{array}{l}16 / 11 \& \\
30 / 11 \\
5-8 \text { p.m. }\end{array}$ & $\begin{array}{l}\text { Definition of giftedness } \\
\text { and talent. }\end{array}$ & Analysis of the concepts and definitions of giftedness and talent. \\
\hline \multicolumn{3}{|r|}{$5^{\text {th }}$ and $6^{\text {th }}$ Meeting } \\
\hline Date/Time & Title & Description \\
\hline $\begin{array}{l}14 / 12 \\
\& 10 / 01 \\
5-8 \text { p.m. }\end{array}$ & $\begin{array}{l}\text { Methods and tests } \\
\text { utilized through the } \\
\text { nomination, } \\
\text { assessment, and } \\
\text { identification of } \\
\text { giftedness and talent. }\end{array}$ & $\begin{array}{l}\text { Discussion of the identification processes of giftedness and talent } \\
\text { in different states in the U.S.A. }\end{array}$ \\
\hline
\end{tabular}




\begin{tabular}{|c|c|c|}
\hline \multicolumn{3}{|r|}{$7^{\text {th }}$ and $8^{\text {th }}$ Meeting } \\
\hline Date/Time & Title & Description \\
\hline $\begin{array}{l}25 / 1 \& \\
\text { o8/o2 } \\
5-8 \text { p.m. }\end{array}$ & $\begin{array}{l}\text { The socio-emotional } \\
\text { needs of gifted and } \\
\text { talented students }\end{array}$ & $\begin{array}{l}\text { Clarification of the social and emotional needs of gifted and } \\
\text { talented students. }\end{array}$ \\
\hline \multicolumn{3}{|r|}{$\mathbf{9}^{\text {th }}$ Meeting } \\
\hline Date/Time & Title & Description \\
\hline $\begin{array}{l}22 / \mathrm{o} 2 \\
5-8 \text { p.m. }\end{array}$ & $\begin{array}{l}\text { Causes and } \\
\text { consequences of poor } \\
\text { development of the } \\
\text { entire potential of } \\
\text { gifted and talented } \\
\text { students }\end{array}$ & $\begin{array}{l}\text { Case studies analysis on the causes of poor academic performance } \\
\text { and dropout rates in the gifted and talented student population. }\end{array}$ \\
\hline \multicolumn{3}{|r|}{$10^{\text {th }}$ Meeting } \\
\hline Date/Time & Title & Description \\
\hline $\begin{array}{l}\text { o8/o3 } \\
5-8 \text { p.m. }\end{array}$ & $\begin{array}{l}\text { Bright delinquent } \\
\text { students }\end{array}$ & $\begin{array}{l}\text { Case studies analysis of the influential environmental factors } \\
\text { through the development of delinquency. Introduction of the } \\
\text { ecological model. }\end{array}$ \\
\hline \multicolumn{3}{|r|}{$11^{\text {th }}$ and 12th Meeting } \\
\hline Date/Time & Title & Description \\
\hline $\begin{array}{l}\text { O5/O4 \& } \\
19 / \mathrm{O} 4 \\
5-8 \text { p.m. }\end{array}$ & $\begin{array}{l}\text { Differentiated } \\
\text { Instruction Strategies } \\
\text { for gifted and talented } \\
\text { students. }\end{array}$ & $\begin{array}{l}\text { Development and implementation of differentiated instruction } \\
\text { strategies in mixed-ability classrooms. }\end{array}$ \\
\hline \multicolumn{3}{|r|}{$13^{\text {th }}$ Meeting } \\
\hline Date/Time & Title & Description \\
\hline $\begin{array}{l}17 / \mathrm{O} 5 \\
5-8 \text { p.m. }\end{array}$ & $\begin{array}{l}\text { Career orientation for } \\
\text { gifted and talented } \\
\text { students. }\end{array}$ & $\begin{array}{l}\text { Case studies analysis on the career preferences and competencies } \\
\text { of } 7 \text { research participants in research that was conducted during } \\
\text { the graduate studies of the program director. }\end{array}$ \\
\hline \multicolumn{3}{|r|}{$14^{\text {th }}$ Meeting } \\
\hline Date/Time & Title & Description \\
\hline $\begin{array}{l}31 / \mathrm{o} 5 \\
5-8 \text { p.m. }\end{array}$ & $\begin{array}{l}\text { Curriculum design for } \\
\text { gifted and talented } \\
\text { students. }\end{array}$ & $\begin{array}{l}\text { Capstone. Portfolio development, by trainees, to incorporate } \\
\text { knowledge and practice (implementation) outcomes. }\end{array}$ \\
\hline
\end{tabular}

\section{Methodology}

The main aim of the present study is to evaluate the effectiveness of Program GATCE and the general impact on participated teachers through their opinions on the strengths and limitations of the Program. Thus, the problem of research is as follows:

What are the views of participants who have been trained in Program GATCE about: a) The Program's design, b) The effectiveness and efficiency of the actions, c) The mechanisms for monitoring, management, and control of the activities, d) The educational material, e) The Skills Certification System, and f) The special and general impact on participated teachers?

\subsection{Rational of Evaluation Methods}

The literature on professional development suggests that for a district program to have high quality, both the design and the evaluation process need to be aligned with the local context, school district's goals and contextual elements (Loucks-Horsley, Hewson, Love, \& Stiles, 1998). In other hand, an evaluation is a problematic enterprise, due to the absent of the appropriate model to the context for which we are seeking to use(Raths, 1988) a different approach to evaluation (Dolyopoulou \& Gourgioitou, 2008; Stufflebeam, 2001) was chosen by the evaluator (University of Crete) through formative assessment and focusing on the nonmanagement-oriented role of the evaluator.

\subsection{Sample}

a) Teachers

Up to 47 kindergarten and primary teachers attended the Program GATCE after filling out an online application form. The number of women [42] was higher than the one of men $[5[$. The ages that responded to the Program are: 25-35 years old [18], 35-45 years old [18], 45-55 years old [11], whereas the number of teachers aged 55-65 was zero. 
A total of 34 teachers lived and worked in the place where the Program was held, 4 of them traveled 45 $\mathrm{km}$ in every session, 6 traveled, $50 \mathrm{~km}$ and 3 were watching through the internet because they were $225 \mathrm{~km}$ away.

As for the grade of education they all served in the first degree and exclusively in public education. The permanent teachers were 44 and the deputies' 3 . Nine out of forty-seven teachers were principals of the schools they served.

Fifteen out of forty-seven teachers declared to have previous working experience in a private school. In the position, they were serving $49 \%$ of the teachers claimed to have 5-10 years of experience, 25.5\% 11-20 years and 21.2\% 21-30 years. During their work in education, two teachers had published articles or conducted researches.

All 47 teachers were graduates of the University of Pedagogical Section, 2 of them had a graduate qualification, 7 had a diploma specialization in special education, 42 had a computer certification, 39 knew English in a reasonable level, and $10 \mathrm{knew}$ 1-2 more languages except English. Forty teachers participated in previous educational workshops with different topics than the current, 2 teachers had participated in educational workshops about management in education, and 5 teachers hadn't participated in educational workshops in the past.

b) Trainers

The trainers' academic and work background was drawn from a variety of specializations like the educational administration, academia, and gifted and talented education, counseling at-risk students, psychology and as parents of gifted and talented students. More specifically, the group of trainers consisted of 5 professionals, 2 of them were academic professors from overseas, one was school counselor and researcher in psychology, one was an educational administrator in the Hellenic Ministry of Education, another one was atrisk counselor and director of a detention center and a parent of a gifted and talented student.

\subsection{Rigor of the Study}

The evaluation process followed the process of the construction of the information from different stakeholders by which the researcher's bias was reduced to demonstrate the criteria of rigour. To establish the internal validity of qualitative research and to identify the effectiveness of the teacher professional development programme a methodological triangulation was used (Burns, 2000; Cohen \& Manion, 1992) with three different methods: interview, observation, and document analysis. The theory of triangulation is related to an epistemological and ontological justification (Merriam, 1988) of the teacher education approaches and evaluation models.

\subsection{Data Collection Analysis and Interpretation Techniques \\ a) Interview}

Interviews have been taken with the identified stakeholders. Specifically, they were structured and unstructured both according to the need of the data. The structured interviews are conducted to get objective information about the training while the unstructured are conducted to identify the interpretation of stakeholders.

\section{b) Observation}

The observation was carried out to identify the dynamics of the training sessions. Specifically, the observation helped assess whether the session has been capable of addressing the needs of teachers.

\section{c) Document and Artefacts Analysis}

Documents related to professional development programme were analysed focusing on whether they are planned and executed consistently. Correctly, the need assessment report, training manuals, and project works were taken into account to analyse the process of evaluation. The document analysis helped identify the programme-related information and its focus on implementation.

Data were interpreted according to the construction and interpretation of the stakeholders. Seamlessly, it does not happen only at the end of the evaluation process; it was a continuous process by which the evaluator developed an integral perspective espousing the stakeholders' perspective.

The evaluator visited the training venue as a process of observation and interviewing, and she prepared a reflective journal after each visit incorporating essential hard and soft data.

\subsection{Ethical Issues}

As stakeholders are the primary sources of data, a written contract for protecting privacy was prepared for each of the stakeholders. The right of anonymity of each stakeholder is respected. For this, the pseudonym of each stakeholder (if essential) was used in the process of analysing the data. The data will be kept confidential and will not be transferred to any other agencies. Furthermore, the questionnaire used to interview respondents was given two days before the interview so that they have time to prepare for the 
questions. Finally, the results of the evaluation of the Program were communicated to all stakeholders in their mail, but also on the Program's and district's website.

\section{Findings}

a) Motivation of the Trained Personnel

$86 \%$ of the teachers had previously attended an educational program in other subjects whereas only $14 \%$ hadn't. The program they had participated in had a positive effect as it enabled them to follow the program under evaluation respectively. The vast majority of the teachers [98\%] were informed about this program from their office. Also, a vast majority of teachers positively evaluate the information and the publicity about the educational programs since $44 \%$ marks them with 5-7 and $46 \%$ over 8 . According to the teachers, the reasons that enabled them to participate in the Program GATCE were:

"... $\tau$ o make good use of the knowledge and the education of the gifted and talented pupils in lesson preparation and teaching” (teacher 12).

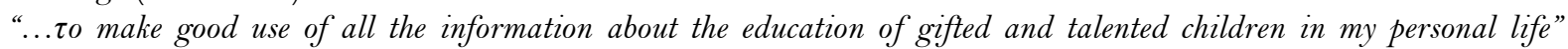
(teacher 26).

“... $\tau$ o enrich my resume and facilitate my personal development” (teacher 43 ).

“... $\tau$ o develop my social and business contacts” (teacher 45).

\section{b) Systematic Provision of Training}

99\% of the trained teachers considered the procedures of onboarding to the Program GATCE flexible and straightforward. The choice of the trainers was exclusively made by the program manager, based on their knowledge related to training of gifted and talented children. As for the co-operation with education consultants who organized the training program, both the trainers and trainees felt it was simple and flexible, and running smoothly. Also, access to the training center (despite being done on their expenses) was "easy" $(77 \%)$ and "quite easy" (19\%). In contrast, $4 \%$ felt it was 'quite difficult'; those were the people who traveled long distances and their time was limited. The time and duration of the classes were "very" or "rather" convenient for $74 \%$ of the teachers. Based on the above we conclude that the preparation for the implementation of the educational programs is positively evaluated by a vast majority of the trained teachers.

\section{c) Organization of the Program GATCE}

The duration of the Program was deemed insufficient by $54 \%$ of the trained teachers. Respectively, that percentage is $74 \%$ for facilitators. The timetable is considered "convenient" or "very convenient" by $56 \%$ of the trained teachers and $70 \%$ of the facilitators. Time allocation between theory and practice is deemed as "appropriate" or "rather appropriate" by $77 \%$ of the teachers and $74 \%$ of the facilitators. The available supervision tools are considered either 'comprehensive' or "adequate" by $95 \%$ of the trained teachers and $92 \%$ of the facilitators. Administrative support of the Program is deemed as "very good" or "sufficient" by $97 \%$ of the trained teachers and $98 \%$ of the facilitators. The available teaching places were "very good" or "sufficient" for the total of the teachers $(100 \%)$ and facilitators $(100 \%)$ in respect. We, therefore conclude that the program's organization is positively evaluated by a vast majority of the trained teachers with the exception of the time duration.

\section{d) Provided Training}

The facilitators' competency was evaluated as "very high" or "high" by $100 \%$ of the teachers. The training schedule against the aim of the training was "complete" or "rather complete" for $71 \%$ of the teachers.

The training material was "adequate" or "satisfactory" for $82 \%$ of the trained teachers. Their quality is considered "high" or "rather high" by $81 \%$ of the teachers. The functionality of the distributed material is evaluated "high" or "rather high" by $78 \%$ of the teachers.

The training enabled participation according to $98 \%$ of participants. It's important to note that the total answers of the facilitators in the same question are similar. An even more encouraging result is that the trained teachers mentioned that the trainers used student-centered teaching methods, such as group projects $(91 \%)$, presentation of the projects $(82 \%)$, and case studies $(89 \%)$.

The provided education met expectations of the needs for gaining knowledge and skills to "a very high" or "satisfactory degree" for $92 \%$ of the total of the trainers. The knowledge and skills that $84 \%$ of the teachers acquired are considered to respond to the needs of their services in a "very high" or "satisfactory degree". As a result, the available education and the acquired knowledge and skills are positively evaluated by the vast majority of facilitators and the trained teachers.

A good proportion of the teachers (75\%) believe the Program GATCE was "adequate", against the aim of the education; whereas $25 \%$ of them believe it was "rather inadequate."

With regards to the training methodology used in the Program, the answers are rather interesting. As expected, the majority of facilitators used lecturing (83\%). This percentage didn't come as a surprise because it is easy to use and because of the short duration of the Program that demands tight time management. However, approximately half of the trainers (51\%) reported that they used group projects, while $42 \%$ of them 
made project presentations. Case studies were used by $75 \%$ of the trainers. These methods are appropriate for teaching adults but also for educating talented and gifted children, which requires the student to be actively involved in the process of learning to produce the desired outcome. When investigating whether participatory teaching methods were used, the results were impressive. As expected, the most significant number of trainers answered that it used these methods (98\%). This result is very positive for the qualitative valuation of the teaching process.

\section{e) Acquired Knowledge and Skills from the Program GATCE}

As for the acquired knowledge, the consultants found below:

The trainees declared that they acquired in a high-level general knowledge about the training of the gifted and talented students $(49 \%)$, the different definitions of giftedness $(46 \%)$, the socio-emotional needs of these children (43\%), while the fourth category of acquired knowledge and skills, were the causes and the consequences of the incomplete development of these children's mental potential (39\%). Some doubts were expressed about the exploitation of knowledge and skills relevant to the detection and evaluation of children $(27 \%)$, the differentiated teaching (23\%), children's vocational guidance $(14 \%)$ and the design of appropriate educational programs (11\%).

The facilitators expressed a positive view on the correspondence of the content of the provided training from the trained teachers, to the needs for gaining knowledge and skills. Specifically, $89 \%$ of the facilitators believe that they responded to a "very high" and "satisfactory degree", while only $11 \%$ to a "low degree." None of the facilitators expressed an entirely contrary view.

As to whether the knowledge and skills that the trained teachers acquired to meet the needs of their offices (question 37), the percentage of those who believe that it responds in a "low degree" is slightly higher $(12 \%)$, while respectively the percentage of those who believe that it responds in a "satisfactory degree" is a little smaller (67\%), as it is the case with those who believe that it responds in a "high degree" (21\%). Interestingly nobody mentioned that it doesn't meet the needs of their service. This slight differentiation we believe that shows the estimation of the facilitators that the knowledge acquired, or indeed the familiarity degree of the teachers, doesn't totally correspond to the needs for the treatment of the gifted and talented children in the real world.

These results show the lack of policy framework in the education of gifted students in Greece. The absent of the legal framework doesn't give to the trained teachers the ability to utilize the knowledge and skills they acquired in the training program during their work.

\section{Benefits for the Trained Teachers from the Program GATCE}

a) Acquisition of Knowledge and Skills

$69 \%$ of the trainees claimed that they are able to utilize the introductory concepts they acquired on the educational policy of gifted students to a "high" or "quite high degree". 58\% of the trained teachers are able to utilize the introductory concepts they acquired in the identification of giftedness in students in theories concerning their socio-emotional needs, in the investigation of the causes and the development of their mental potential in full in a "rather high degree" and $42 \%$ in "medium degree". The equivalent percentage for potentially delinquent students with high mental potential is $74.6 \%$, while it stands at $47.4 \%$ for professional orientation of gifted students. Finally, $44 \%$ of the trained teachers were able to use differentiation teaching and design methods of the training program.

\section{b) Application of Knowledge and Skills Acquired}

Utilization of the knowledge and skills acquired $68 \%$ of the trained teachers use the introductory concepts of training gifted students for the preparation of their daily teaching in a "high" or "maybe high degree". The trainees' stance

Following the Program GATCE contributed in a "high" or "rather high" degree in increasing their selfesteem (92\%), developing sense of independence (91\%), being satisfied for successfully completing something $(98 \%)$, in creating ambitions $(84 \%)$, developing sense of trust for people $(86 \%)$, getting to know the enjoyment of learning (91\%), developing an innovative spirit (75\%) and recognition of the value of learning (94\%).

"... The completion of the Program GATCE enabled me to see the people around me in a more positive way and wanting to contribute to the development of my community” (teacher 4).

"...After the completion of the Program GATCE I put some goals in life which I try to achieve" (teacher 17).

“...After the completion of the educational program it's easier for me to generate new ideas and I experiment” (teacher 21).

“...After the completion of the Program GATCE I can create new things" (teacher 23).

"...Watching the Program GATCE was what motivated me to move on to other studies or follow other educational programs”(teacher 39 ). 


\section{Discussion - Conclusions}

In this study, it has been examined the effectiveness of the in-service teachers' training program on gifted education.

The conclusions that the emerged from the application of the evaluation project, per assessment module, are the following: Evaluation of the training program design. The implementation of the training program is a necessary intervention for the education of the gifted students, which is essential in educational activity. However, the evaluated training program is necessarily sufficient to achieve the above objective.

\section{a) Evaluation of the Program GATCE Design}

The implementation of additional actions is required, the major of that is the realization of a second educational cycle for the expansion and focus of the gained knowledge and skills. The training program's effectiveness and efficiency evaluation. Based on the evidence that the Evaluation Consultant has in hand, the effectiveness indicator as much as the Indicator of the effectiveness of the act displays absolutely satisfying levels.

According to the evidence that the Evaluation Consultant has in hand, the effectiveness indicator as much as the indicator of the efficiency of the act displays absolutely satisfying levels.

\section{b) Evaluation of Monitoring Mechanisms and Action Plan Management of the Program GATCE}

The evaluator believes that the training program was designed and implemented to a satisfactory degree. Through implementation System Management, Monitoring, Evaluating, and project's implementation, all the people involved have been aware of what their role and responsibilities were. Which resulted in the positive project's implementation which contradicts the findings of Vidergor and Eilam (2011) which had a limited impact on teachers' participation. This information was available on the websites of the sectors, while they were also shared as official documents and bulletins to everybody involved. There weren't any institutional or administrative goals, since the Handling System of the training program describes all the aspects of the project, while it was continually improving during the implementation.

It has been seen, also, that the cooperation between the stakeholders involved (school units, administrative executives, school counselors, educators, and university) was outstanding and easy, based on the fact that all stakeholders had certain duties. Respectively the procedures of coordination between stakeholders were excellent without causing any problems. The speed of decision-making and the dissemination of information were satisfying. The monitoring procedures of the training program ensured a positive implementation. The "Training System" in which there are recorded procedures in matters of the implementation of them, the person's responsibility who is implementing the training program, the correlation of the procedures with the associated entities of implementation and the related issues in organization consisted a quality control system for the project. The monitoring mechanisms (from the lowest to highest level) paid off. Hence, certification delivery had delays due to the lack of communication among the lack of compatibility between the education and certification system. The issue solved due to the flexibility that the educational counselors showed. The trainers responded to the project's needs and requirements with the best possible ways (responsibility and professionalism).

\section{c) Skills Certification System of the Program GATCE}

According to both, the trainers and the trained teachers, the educational material was of the highest quality. The texts and slides used were high quality in all aspects; design, structure, organization, content, illustration. The instruments for the identification and evaluation of the gifted students were correctly translated and formulated in the Greek language, and easily used.

The themes and content of the work plans were set based on the criteria. They corresponded to the learning goals; they were formulated with clarity, covered the curriculum standards and the kind of thematic concern, and also enabled the total of skills that were developed during the training.

\section{d) Evaluation of the effects of the Program GATCE}

They were distinguished for their uniqueness, creativity, and innovation and showed that work-plan method could be a good alternative for program certification.

The benefits for the trained teachers are essential $82 \%$ of them certify the qualifications they gained through the work-plans and this percentage is expected to increase shortly. The majority of the trained teachers are able to utilize the knowledge and skills they acquired for the project. The majority of the trained teachers who utilize the acquired knowledge and skills during their teaching is also an important finding that increased their self-efficacy for academic research mentorship in gifted education (Tortop, 2014). The contribution of the training program in shaping a more positive attitude on teachers is impressive. The increase of self-esteem, developing sense of independence, the satisfaction because "they completed something successfully," the enjoyment of learning, the rise of the spirit of innovation and the acknowledgment of the value of knowledge for the majority of the trained teachers, are accounted to the essential positive effects of the training program. Also noteworthy was the contribution of the training program in forming a positive attitude 
on teachers towards the community they live in, to the enactment of particular targets and to the effort for achieving them, encouraging innovation, urging to monitor other educational programs/training.

In conclusion, the highest percentage of teachers has a positive view of the integration process of the training program. The access to the educational services, the time and duration of classes was good enough for most of the trained teachers. The organization of the training program is positively evaluated by the highest percentage of trained teachers. However, the duration of the training program was found inadequate from most of the trained teachers. The training provided, and the gained knowledge and skills are positively evaluated by the majority of the trained teachers with the exception the non-implementation of participatory teaching methods for most of the questioned.

\section{Recommendations}

From the above conclusions and from the research that has already been conducted in the areas of gifted education and teachers' training some interesting proposals came up, which are presented below:

The trainers, the school counselors, and trainees expressed that the duration of the training program was too short for beginner in-service teachers to acquire enough knowledge on the education of the gifted students. Similar research results are found in the research of Sayı (2018) where participated teachers stated that was needed to have more time to carry out such training. The training hours were very few to cover-up the curriculum standards, for the personalized teaching in cases that was needed, and for practice on the training of gifted students, which required specific authorization by the Ministry of Education. What is suggested is either for a preliminary level for beginners to be developed or for the choice of classes to be done based on the level of knowledge to the training of gifted students. Concerning the educational material should be better distributed ahead of the training program in order to teachers to have the time to study before and during the implementation of the training. It is suggested, also, to encourage the broader application of participatory teaching methods, to ensure the compatibility between training system and certification system, and to make sure that all trainers are widened by including people who are informed on the subject of training and have experience in organizing and managing such projects. Finally, GATCE evaluation results can be utilized to examine the possibility of decentralization of the project management system as a regional level and granting more duties to school districts to show greater flexibility in the implementation of the training program.

\section{References}

Burns, R. B. (2000). Introduction to research methods. French Forest: Pearson Education Australia.

Choe, H. S. (2011). In-service training program for the teacher observation-recommendation for the gifted students. Changwon: Gyeongnam Office of Education.

Choe, H. S. (2016). Critical reflection on teacher training programs in Korean gifted and talented education. Turkish Journal of Giftedness and Education, 6(1), 35-43.

Cohen, L., \& Manion, L. (1992). Research methods in education. New York: Routledge.

Dolyopoulou, E., \& Gourgioitou, E. (2008). Assessment in education. Athens: Gutenberg.

Fraser-Seeto, K. (2013). Pre-service teacher training in gifted and talented education: An Australian perspective. Engagement. The Journal of Student: Education Matters, 3(1), 29-38.

Gardner, H. (1983). Frames of mind: the theory of multiple intelligences. New York: Basic Books.

Gross, M. U. M., MacLeod, B., Bailey, S., Chaffey, G., Merrick, C., \& Targett, R. (2004). Gifted and talented education. Professional development package for teachers. Gifted Education Research, Resource and Information Center (GERRIC), The University of New South Wales (UNSW), Sydney, NSW, Australia.

Grow-Maienza, J. (1996). Philosophical and structural perspectives in teacher education. In F. B. Murray (Ed.), The teacher educator's handbook: Building a knowledge base for the preparation of teachers. San Francisco: Jossey-Bass.

Hansen, J. B., \& Feldhusen, J. F. (1994). Comparison of trained and untrained teachers of gifted students. Gifted Child Quarterly, 38(3), 115-121.

Heller, K. A. (1992). Giftedness research and education of the gifted and talented in Germany. In Mönks, F. J., Katzko M. W., \& Boxtel H. W. (Eds.), Education of the gifted in Europe: Theoretical and research issues (pp. 71-86). Assent: The Netherlands: Van Gorcum.

Johnsen, S. K. (2003). Identifying gifted students: A practical guide. Waco: TX: Prufrock Press, Inc.

Kabadayi, A. (2016). A suggested in-service training model based on Turkish preschool teachers' conceptions for sustainable development. Journal of Teacher Education for Sustainability, 18(1), 5-15.

Law, n. (3194/2003). (20.11.2003, article 2, paragraph 7a, page 4659) added a statement to the article 1, paragraph 2, page 78 of Law $2817 / 2000$.

Law, n. (3699/2008). Special education and training for people with disabilities or special educational needs Government Gazette 199, 02.10.2008, article 3, paragraph 3, page 3500.

Loucks-Horsley, S., Hewson, P. W., Love, N., \& Stiles, K. (1998). Designing professional development for teachers of science and mathematics. Thousand Oaks, CA: Corwin.

Merriam, S. B. (1988). Case Study approach: A qualitative approach. San Francisco: Jossey Bass.

Milgram, R. M. (1991a). Career education for gifted and talented learners. In R. M.Milgram (Ed.), Counselling gifted and talented children: A guide for teachers, counsellors, and parents. Norwood: NJ: Ablex. 
Milgram, R. M. (1991b). Counselling gifted and talented children and youth: Who, where, what, and how? In R. M. Milgram (Ed.), Counselling gifted and talented children: A guide for teachers, counsellors, and parents (pp. 7-21). Norwood, NJ: Ablex.

Mönks, F. J., \& Pfluger, R. (2005). Gifted education in 21 European countries: Inventory and perspective. Radboud University Nijmengen.

NAGC, \& CDGP. (2013). State of the states in gifted education. . Washington: DC: Author.

Pfeiffer, S. I. (2012). Current perspectives on the identification and assessment of gifted students. Journal of Psychoeducational Assessment, 30, 3-9. Available at: 10.1177/0734282911428192.

Pfeiffer, S. I. (2015). The tripartite model on high capacity and best practices in the evaluation of the ablest. Education Magazine, 368, 66-95. Available at: 10.4438/1988-592X-RE-2015-368-293.

Raths, J. D. (1988). Evaluation of teacher education programs. In W. G. Gephart \& J. B. Ayers (Eds.), Teacher education evaluation. Boston: Kluwer Academic Publishers.

Reid, E., \& Horváthová, B. (2016). Teacher training programs for gifted education with focus on sustainability. Journal of Teacher Education for Sustainability, 18(2), 66-74.

Renzulli, J. S. (1978). What makes giftedness? Reexamining a definition. Delta Kappan, 60(261), 180-184.

Renzulli, J. S. (2012). Reexamining the role of gifted education and talent development for the 21 st century: A four-part theoretical approach. Gifted Child Q 56,150-159. Available at: 10.1177/0016986212444901.

Sayı, A. K. (2018). Teachers' views about the teacher training program for Gifted Education. Journal of Education and Learning, 7(4), 262-273.

Sparks, D., \& Loucks-Horsley, S. (1989). Five models of staff development. Journal of Staff Development, 10(4), 40-57.

Stufflebeam, D. (2001). Evaluation models. New Direction for Evaluation, 2001(89), 7-98.

Tomlinson, C. (2001). How to differentiate instruction in mixedability classrooms (2nd ed.). Alexandria, VA: Association for Supervision and Curriculum Development.

Tortop, H. S. (2014). Examining the effectiveness of the in-service training program for the education of the academically gifted students in Turkey: A case study. Journal for the Education of the Toung Scientist and Giftedness, 2(2), 67-86.

Tourón, J., Peralta, F., \& Repáraz, C. (1998). Intellectual giftedness. models, identification and educational strategies. Pamplona: EUNSA.

Tourón, J., Repáraz, C., \& Peralta, F. (2006). Nominations of teachers in identifying students of high intellectual capacity. Sobredotação, 7, 7-25.

UNESCO. (1994). The Salamanca statement and framework for action on special needs education. Adopted by the world conference on special needs education: Access and equity. Paris: UNESCO.

Van Tassel-Baska, J., \& Johnsen, S. K. (2007). Teacher education standards for the field of gifted education: A vision of coherence for personnel preparation in the 21 st century. Gifted Child Quarterly, 51(2), 182-205.

Vidergor, H. E., \& Eilam, B. (2011). Impact of professional development program for teachers of the gifted. Gifted and Talented International, 26(1-2), 143-161.

Vygotsky, L. (1997). Educational psychology. Boca Raton, FL: St. Lucie Press. 